\title{
NOTE ON TRANSLITERATION AND PERSONAL NAMES
}

For Japanese, I follow a modified Hepburn transliteration system, with occasional exceptions made for the particularities of classical Japanese orthography. As for the use of Japanese characters, I have usually followed the custom of silently modernizing older forms of kanji and kana. In many of the poems, however, I hew closely to the older orthography, for which I have an affection.

When giving the title of a text originally written in Japanese, I generally provide an English translation of the title, then in parentheses a transliteration of the Japanese title followed by the original title in Japanese characters. For works of high historical import, however, I reverse this order, presenting the Japanese titles first with an English translation following in parentheses.

For Chinese, I use Pinyin transliteration.

All translations are my own unless otherwise indicated.

When quoting from Japanese critical writings, if an aspect of the diction or orthography strikes me as being potentially noteworthy, I represent the original text by including a transliteration followed by Japanese characters. At times, however, I omit the Japanese characters if the original would be clear from the transliteration alone.

The first mention of a Japanese personal name is presented in Japanese order: family name followed by given name, which is the reverse of the Western order.

The handling of subsequent mentions of personal names is complicated by the fact that many Japanese writers of the period I treat in this book are commonly known not by their given name (honmyō or honmei) but rather by their pen name or nom de plume ( $g \bar{o}$ or $g a g \bar{o})$. For example, the novelist who was born Natsume Kinnosuke (family name Natsume) took the pen name Natsume Sōseki, which is conventionally shortened to Sōseki in critical writings about his work. In the main, I have tried to follow Japanese critical convention on personal names: hence, I refer to the poet Takamura Kōtarō as Takamura, but the poet Kanbara Ariake as Ariake. 
Where I have found Japanese critical convention to be inconsistent-for example, some Japanese literary critics refer to Hattori Yoshika as Hattori, some as Yoshika - I generally default to the family name. The details are labyrinthine, but for now let this note suffice. 
THE ENDS OF METER IN MODERN JAPANESE POETRY 
